\title{
Phytochemical Composition and Evaluation of Marine Algal Sargassum polycystum for Antioxidant Activity and In Vitro Cytotoxicity on Hela Cells
}

\author{
Ade Arsianti ${ }^{1,2, *}$, Anton Bahtiar ${ }^{3}$, Vincent Kharisma Wangsaputra ${ }^{4}$, Norma Nur Azizah' ${ }^{2}$, Wilzar Fachrii, ${ }^{5,2}$, Lince \\ Dameria Nadapdap ${ }^{2}$, Ajeng Megawati Fajrin' ${ }^{1}$, Hiroki Tanimoto ${ }^{6}$, Kiyomi Kakiuchi ${ }^{6}$
}

Ade Arsianti ${ }^{1,2, *}$, Anton Bahtiar ${ }^{3}$, Vincent Kharisma Wangsaputra4, Norma Nur Azizah², Wilzar Fachri ${ }^{5,2}$, Lince Dameria Nadapdap ${ }^{2}$, Ajeng Megawati Fajrin ${ }^{1}$, Hiroki Tanimoto ${ }^{6}$, Kiyomi Kakiuchi ${ }^{6}$

'Department of Medical Chemistry, Faculty of Medicine, University of Indonesia, Jakarta INDONESIA.

${ }^{2}$ Drug Development Research Cluster, Indonesia Medical Education and Research Institute (IMERI), Faculty of Medicine, University of Indonesia, Jalan Salemba Raya 6 Jakarta 10430, INDONESIA.

${ }^{3}$ Department of Pharmacology, Faculty of Pharmacy, University of Indonesia, Depok, INDONESIA.

${ }^{4}$ Medical Student Faculty of Medicine University of Indonesia, Jakarta, INDONESIA. ${ }^{5}$ Department of Medical Pharmacy, Faculty of Medicine, University of Indonesia, Jakarta INDONESIA.

${ }^{6}$ Graduate School of Materials Science, Nara Institute of Science and Technology (NAIST), 8916-5 Takayama-cho, Ikoma, Nara, JAPAN.

\section{Correspondence}

\section{Dr. Ade Arsiant}

Department of Medical Chemistry, Faculty of Medicine University of Indonesia Depok, INDONESIA.

Phone no: +6281312581253

E-mail: arsi_ade2002@yahoo.com

History

- Submission Date: 01-12-2019;

- Review completed: 18-12-2019;

- Accepted Date: 23-12-2019.

DOI : $10.5530 / p j .2020 .12 .14$

Article Available online http://www.phcogj.com/v12/i1

\section{Copyright}

(C) 2020 Phcogj.Com. This is an openaccess article distributed under the terms of the Creative Commons Attribution 4.0 International license.

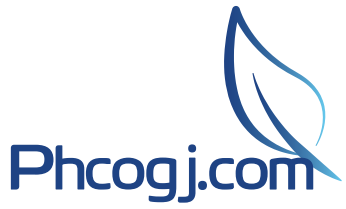

\begin{abstract}
Introduction: Sargassum polycystum is one of marine algal which has a potent antioxidant anticancer activities. This research aims to investigate phytochemical composition, antioxidant activity, and in vitro cytotoxicity of marine algal Sargassum polycystum on cervical HeLa cancer. Methods: Sargassum polycystum collected from Dompu beach, Lombok, Nusa Tenggara Barat Province, Indonesia, were extracted into organic solvent of $n$-hexane, ethylacetate, chloroform and ethanol, respectively. Subsequently, Sargassum polycystum extracts were applied for Thin Layer Chromatography (TLC) analysis, phytochemistry test, total phenolic and total flavonoid contents, as well as for antioxidant activity test by DPPH (2,2-diphenyl-1-picrylhydrazyl) method, and in vitro cytotoxicity evaluation on HeLa cells by MTT (3-[4,5-dimethylthiazol-2-yl]-2,5diphenyltetrazolium bromide) assay. Results: Phytochemical analysis of $S$. polycystum extracts are positive for metabolites of flavonoid, steroid, tannin and glycoside. TLC analysis revealed that S. polycystum extracts containing four phytochemical components. Ethylacetate extract of S. polycystum showed the highest total phenolic content, and exhibited greater antioxidant activity than ethanol extract. Total phenolic and total flavonoid content in ethylacetate extract are $548.61 \mu \mathrm{g} / \mathrm{mL}$ and $40.06 \mu \mathrm{g} / \mathrm{mL}$, respectively. Ethylacetate extract of S. polycystum with $\mathrm{IC}_{50}$ value of $298.3 \mu \mathrm{g} / \mathrm{mL}$ is assigned to have a weak antioxidant activity against DPPH free radical. The results indicate that antioxidant activity of ethylacetate extracts of $S$. polycystum is directly correlated with its total phenolic and flavonoid content. Moreover, S. polycystum extracts demonstrated a strong anticancer activity on cervical HeLa cells with $\mathrm{IC}_{50}$ ranging from $38.3 \mu \mathrm{g} / \mathrm{mL}$ to $112.8 \mu \mathrm{g} / \mathrm{mL}$. Conclusion: This work confirmed that S.polycystum are promising natural antioxidant and anti-cervical cancer agents.
\end{abstract}

Key words: Sargassum polycystum, phytochemisty, antioxidant, cytotoxicity, HeLa cells.

\section{INTRODUCTION}

Cancer is one of the diseases that is life-threatening and health-threatening in the world as well as in Indonesia. According to data obtained from the Information Center on human papiloma virus (HPV) and Cancer in 2017 in Indonesia, breast cancer and cervical cancer rank the first and second most cancer incidents suffered by women respectively, with the number of cases 39.9 and 17.0 per 100,000 population. ${ }^{1}$ The data showed that the prevalence of cervical cancer is quite high in Indonesia. Various attempts have been made to cure cancer which include surgical methods, chemotherapy, hormonal therapy, radiotherapy or combinations of these methods. However, studies conducted by Lage (2003) and Aziz (2006) revealed that some of the previously mentioned healing methods not only cause side effects to occur, but also show resistance to cancer cells, so that they are no longer effective to be applied. ${ }^{2,3}$ One of the marine biota that has fairly high diversity and shows anticancer activity is marine macroalga. Korean researchers reported that the cell wall of brown macroalgae Fucus vesiculosus contains sulphate polysaccharide compound, fucoidan, that shows anticancer activity by inducing apoptosis in HCT116 colorectal cancer cells. ${ }^{4}$ In 2013, researchers from China revealed that extract of water macroalgae Sargassum oligocystum inhibited the leukemia cancer cells proliferation, whereas heterofucan compounds isolated from brown macroalga Sargassum filipendula showed antiproliferative effects on cervical and prostate cancer cells. ${ }^{5}$ Michanek (1979) and Noda et al. (1990) reported that Sargassum sp. is an anticancer macroalga species that is mostly found in Indonesian marine. ${ }^{6,7}$ The anticancer potential of macroalga Sargassum sp., has inspired us to conduct studies that aim to develop Indonesian marine natural products that focus on the exploration of macroalga Sargassum polycystum which is widely available in the coastal areas of Indonesia, as novel potential anticancer. Recently in 2019, we have completed cytotoxicity evaluation of $S$. polycystum extracts originated from Lengkuas beach, Tanjung Pandan, Belitung, Indonesia, which showed a strong cytotoxicity against colon HCT-116 and lung-A549 cells. ${ }^{8}$ In this current work, the specific objectives which will be achieved is to obtain S. polycystum extract using maceration and extraction techniques; to perform phytochemical analysis and thin layer chromatography (TLC) of S.polycystum extract; to

Cite this article: Arsianti A, Bahtiar A, Wangsaputra VK, Azizah NN, Fachri W, Nadapdap LD, et al. Phytochemical Composition and Evaluation of Marine Algal Sargassum polycystum for Antioxidant Activity and In Vitro Cytotoxicity on Hela Cells. Pharmacog J. 2020;12(1):88-94 
determine total phenolic and total flavonoid contents of the extract; to evaluate its antioxidant activity and in vitro cytotoxicity against cervical HeLa cells.

\section{MATERIAL}

\section{Marine Algal Sargassum polycystum}

Sargassum polycystum were collected from Dompu beach, Nusa Tenggara Barat, Indonesia (Figure 1).

The morphology of S. polycystum is cylindrical talus with small thorns, holdfast forms a small disc and on its top, there is a stolon root which expands to all directions. Short stems with branches, have air bubbles (bladder) which are generally in groups, reaching 7 metres in length, with the brown color of the talus generally, ${ }^{9,10}$ The habitat where the $S$. polycystum can grow is widely spread in Indonesia. In Kepulauan Seribu, another area in Indonesia, Sargassum sp. is called oseng, whilst in Banten this marine algal is known as kembang karang or coral flower. Sargassum sp. flourish well in the tropics with water temperatures of $25-30^{\circ} \mathrm{C}$, salinity of $32-33.5 \%$, and sunlight intensity ranging from 6500 to 7500 lux. The environment where Sargassum sp. grows is usually in clear waters that have the basic substrate composition of a coral reef, dead coral, and volcanic rock. The southern coast of Java, the Sunda Strait, some of the islands in Batam and Bangka-Belitung province in Indonesia that have beaches with coral reef substrate, are ideal habitats for the marine algal Sargassum sp. ${ }^{11}$

\section{Cervical HeLa cancer cell lines}

Cervical HeLa cancer cell is the cell culture collection of the Medical Chemistry Department, Faculty of Medicine, University of Indonesia.

\section{METHODS}

\section{Extraction of Marine Algal Sargassum polycystum}

Maceration and extraction technique of marine algal S. polycystum as follows, 250 gram of dried powder of marine algal Sargassum polycystum is macerated with each n-hexane, chloroform, ethylacetate, and ethanol solvents in a tightly closed glass vessel for 7 days, with occasional stirring. Maceration is done three times to extract as

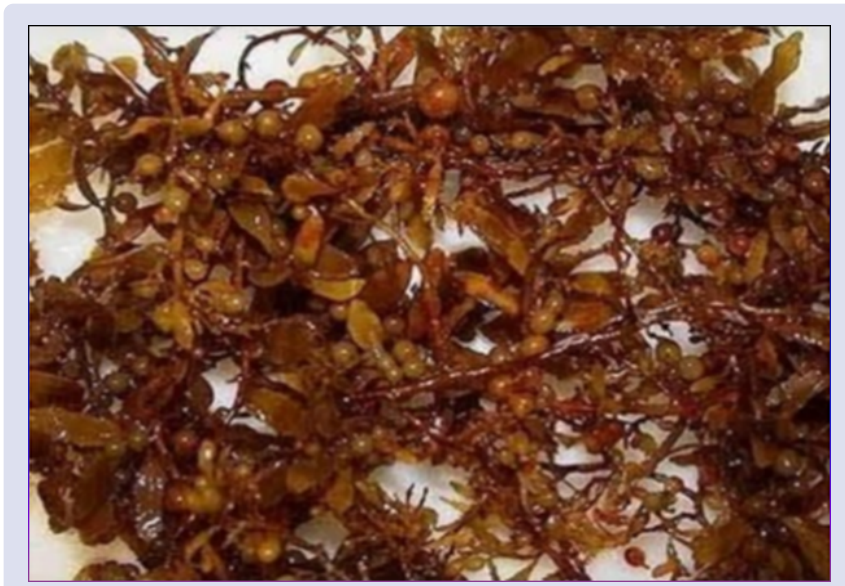

Figure 1: Sargassum polycystum

Kingdom : Chromista

$\begin{array}{ll}\text { Division } & : \text { Phaeophyta } \\ \text { Class } & : \text { Phaeophyceae } \\ \text { Order } & : \text { Fucales } \\ \text { Family } & : \text { Sargassaceae } \\ \text { Genus } & : \text { Sargassum } \\ \text { Species } & : \text { Sargassum polycystum }\end{array}$

much substances as possible from algal powder. The mixture of the maceration process are then filtered, the filtrates are concentrated using a rotary evaporator, to produce crude extract of n-hexane, chloroform, ethylacetate and ethanol, respectively. Extracts obtained are then applied for phytochemical test, total phenolic and total flavonoid contents, as well as Thin-Layer Chromatography (TLC) analysis to determine how many chemical components contained in the extracts. Subsequently, antioxidant activity of Sargasssum polycystum extracts were determined by DPPH method. Furthermore, the cytotoxic activity of the four extracts of Sargassum polycystum towards cervical HeLa cells will be tested in vitro by using the MTT cell proliferation assay.

\section{Phytochemistry test}

Phytochemistry test is performed to identify the content of chemical secondary metabolites, such as saponin, flavonoid, triterpenoid, steroid, glycoside, tannin and alkaloid in the extract. Procedure of phytochemistry test was adopted from Harborne $(1987)^{12}$ and Ciulei $(1982)^{13}$, and was conducted as described in our previous research. ${ }^{8}$

\section{Determination of total phenolic content}

Total phenolic content in S. Polycystum extracts were determined by procedure provided by Banerjee et al $(2008)^{14}$, with some modifications. A stock solution was prepared by dissolving folin ciocalteu phenol reagent in distilled water $(1: 10)$, amount of $100 \mathrm{~mL}$ aqueous solution of $\mathrm{Na}_{2} \mathrm{CO}_{3}$ at the concentration of $2 \%(\mathrm{~b} / \mathrm{v})$ was also prepared. S.polycystum extract $(10 \mathrm{mg})$ was dissolved in $75 \%$ of ethanol $(10 \mathrm{~mL})$, subsequently, triplicates of 0.5 mLdiluted S.polycystum extract were added into the test tubes and mixed with $1 \mathrm{~mL}$ of $\mathrm{Na}_{2} \mathrm{CO}_{3}$ solution. The mixture in the test tubes were then added $0.5 \mathrm{~mL}$ folin ciocalteu stock solution, the mixture was then incubated in a dark chamber. After incubation in 30 minutes, the mixture was analyzed by visible spectrophotometer at wavelenght of $765 \mathrm{~nm}$. Blank solution was prepared with the same procedure mentioned previously, but without addition of $S$. polycystum extract. Whereas standard solutions were prepared by diluting 1000 $\mu \mathrm{g} / \mathrm{mL}$ of gallic acid with $75 \%(\mathrm{v} / \mathrm{v})$ of ethanol until reached one-set variety concentration of gallic acid standard solution at $0,6.25,12.5$, 25,50 , and $100 \mu \mathrm{g} / \mathrm{mL}$. The absorbance of gallic acid standard solutions were measured with UV-Visible Spectrophotometer at $765 \mathrm{~nm}$, and plotted The absorbance versus concentration for linear regression. The absorbance of triplicate extract samples was averaged, the average of absorbance value was inputted and interpolated into the linear regression equation of standard solution gallic acid to obtain total phenolic content of extract sample in $\mu \mathrm{g} / \mathrm{mL}$.

\section{Determination of total flavonoid content}

Determination procedure of flavonoid content was modified from Do et al. (2014). ${ }^{15}$ S.polycystum extract $(10 \mathrm{mg})$ was dissolved in $75 \%$ of ethanol $(10 \mathrm{~mL})$, subsequently, $600 \mu \mathrm{L}$ of the extract (triplicates) were placed into the test tubes and were added $20 \%$ of $\mathrm{AlCl}_{3}(30 \mu \mathrm{L})$ and $2 \mathrm{M}$ $\mathrm{CH}_{3} \mathrm{COOK}(30 \mu \mathrm{L})$. The mixture was then added distilled water until reach volume $1.5 \mathrm{~mL}$ and homogenized by vortex mixer. The blank solution was prepared by the same procedure, but without addition of the extract. All mixture solutions in test tubes were incubated in the dark chamber at room temperature. After incubation for 30 minutes, the absorbance values of mixture solutions were measured UV-Vis spectrophotometer at $440 \mathrm{~nm}$.

Standard solutions at the variety concentration of $0,6.25,12.5,25,50$, and $100 \mu \mathrm{g} / \mathrm{mL}$ were prepared by diluting $1000 \mu \mathrm{g} / \mathrm{mL}$ of quercetin with $75 \%(\mathrm{v} / \mathrm{v})$ of ethanol. The absorbance of quercetin standard solutions were measured with UV-Visible Spectrophotometer at $440 \mathrm{~nm}$. Linear regression graph was generated by plotting the absorbance versus concentration for linear regression. The absorbance of triplicate extract samples was averaged, the average of absorbance value was inputted and 
interpolated into the linear regression equation of standard solution to obtain total flavonoid content of extract sample in $\mu \mathrm{g} / \mathrm{mL}$.

To determine total phenolic content in the extract, the absorbance of triplicate extract samples was averaged, the average of absorbance value was inputted and interpolated into the linear regression equation of standard solutions of quercetin.

\section{Thin layer chromatography (TLC) analysis}

Thin layer chromatography (TLC) is a useful method to identify and separate chemical substances in the crude extract based on its polarity and consisting of a mobile phase and the stationary phase. The stationary phase is the TLC plate combined with adsorbent material, such as silica gel. In this work, silica gel plates was used as a stationary phase, whereas the mixture of chloroform $\left(\mathrm{CHCl}_{3}\right)$ and methanol $\left(\mathrm{CH}_{3} \mathrm{OH}\right)$ was used as a mobile phase. The sample extract was dropped on the silica gel plate using capillary tube. Then, the silica gel plate was placed into the isolated chamber. The chemical components containing in the extract will move in different rates depending on the polarity and will appear as spot on silica gel plate. UV light at the wavelength of $254 \mathrm{~nm}$ and 366 $\mathrm{nm}$ is used as visualized spot.

Retention factor (Rf) of each spot of chemical compound can be calculated by the formula:

$\mathrm{Rf}($ Retention factor $)=$ distance traveled by sample/ distance traveled by mobile phase

\section{Determination of antioxidant activity by DPPH method}

DPPH radical scavenging method used in this work was adopted from Rajurkar and Hande (2011) ${ }^{16}$. DPPH fresh solution in concentration of $100 \mathrm{ppm}$ was prepared by dissolving $5 \mathrm{mg}$ of DPPH with $75 \%$ of ethanol $(50 \mathrm{~mL})$ in dark condition by storing it in amber glass bottle covered in aluminium foil at room temperature. S. polycystum extract and ascorbic acid (a positive control) in concentration of $500 \mathrm{ppm}$ was prepared by dissolving $5 \mathrm{mg}$ of $S$. polycystum extract and $5 \mathrm{mg}$ ascorbic acid with $75 \%$ of ethanol $(10 \mathrm{~mL})$, respectively. Subsequently, 500 ppm of $S$. polycystum extract was diluted with $75 \%$ of ethanol to give extract sample solution of $S$. polycystum in concentration of $6.25,12.5$, 25,50 , and $100 \mathrm{ppm}$ (triplicates). Whereas serial ascorbic acid solution in concentration of $3.125,6.25,12.5,25$ and $50 \mathrm{ppm}$ were prepared by diluting $500 \mathrm{ppm}$ of ascorbic acid solution with $75 \%$ of ethanol. Subsequently, $1.5 \mathrm{~mL}$ of each concentration of extract sample solutions and $1.5 \mathrm{~mL}$ of each concentration of ascorbic acid solutions were placed into the test tubes and were added $1.5 \mathrm{~mL}$ of DPPH solution, respectively. The blank solution was prepared by the same procedure, but without addition of the extract solution or ascorbic acid solution. All of the mixtures in test tubes were incubated for 30 minutes in dark isolated system at room tempereture. After incubation in 30 minutes, the mixtures were then transferred into cuvettes and measured the absorbance with UV-Vis spectrophotometer at $517 \mathrm{~nm}$.

DPPH radical scavenging activity of the sample (\%inhibition on DPPH) is calculated using

DPPH $\%_{\text {Inhibition }}=\frac{A_{\text {control }}-A_{\text {extract }}}{A_{\text {control }}} \times 100 \%$

$\mathrm{A}_{\text {control }}$ is an absorbance of control DPPH solution (100 ppm) and $\mathrm{A}_{\text {extract }}$ is the absorbance of samples, either ascorbic acid solutions or $S$. polycystum extract solutions). The absorbance value is an average from triplicates which subtracted with blank absorbance. A linear regression equation: $y=a x+b$, is obtained by plotting DPPH \% inhibition of sample with the concentration. The $\mathrm{IC}_{50}$ value of the sample (either extract of $S$. polycystum and ascorbic acid) were generated by substitute the coefficient $\mathrm{y}$ with value of 50 to give the coefficient $\mathrm{x}$ value, which equal to $\mathrm{IC}_{50}$ value

\section{In vitro Cytotoxicity Evalution by MTT assay}

Cervical HeLa cancer cells were seeded in RPMI 1640 (Gibco, USA) culture medium, which has been supplemented with $10 \%$ fetal bovine serum (Gibco, USA). Then, it is incubated at $37^{\circ} \mathrm{C}$ in a humidified atmosphere of $5 \% \mathrm{CO}_{2}$. The cell viability is determined by $0.1 \%$ trypan blue method. Each extract sample of $S$. polycystum were diluted until reach the serial final concentration of $51.2 ; 25.6 ; 12.8 ; 6.4 ; 3.2 ; 1.6$; 0.8 and $0.4 \mu \mathrm{g} / \mathrm{ml}$. Subsequently, diluted extract samples were added separately to the target cells and incubated for 48 hours. Amount of 100 $\mu \mathrm{l}$ of $5 \mathrm{mg} / \mathrm{mL}$ of MTT phosphate-buffered saline (PBS) was then added into the target cells in the well plate, and the mixture in the well plate was reincubated for 4 hours. The mixture was then centrifuged, the medium is separated. About $100 \mu \mathrm{l}$ DMSO is added to each well to dissolve the blue purple-colored sediments. The absorbance is measured at $590 \mathrm{~nm}$ on a microplate reader (Model 550, Bio-Rad, USA) at the wavelength of $590 \mathrm{~nm}$. The percentage of inhibition was calculated using the formula:

$\%$ inhibition $=1-\left(\frac{\text { Absorbance of treatment group }}{\text { Absorbance of control group }}\right) \times 100 \%$

Cytotoxicity of the samples of S. polycystum extracts on HeLa cells are expressed by median inhibitory concentration $\left(\mathrm{IC}_{50}\right)$ value.

\section{RESULTS AND DISCUSSION}

\section{Phytochemistry of Sargassum polycystum}

Phytochemistry test for extract of $\mathrm{n}$-hexane, ethyl acetate, Chloroform and ethanol of $S$ polycystum is summarized in Table 1. As shown, non-polar extract of $\mathrm{n}$-hexane and chloroform of S.polycystum showed positive result for metabolites of flavonoid, steroid, tannin, and glycoside. Semi polar extract of ethyl acetate and polar extract of ethanol showed positive result for flavonoid, steroid, and glycoside. This phytochemistry results supported by Mehdinezhad et al. (2016) that reported the three species of marine algal Sargassum sp. i.e. S.angustifolum, S.boveanum, and S.oligocystum, originated from Province of Bushehr, Iran containing phytochemical metabolite of tannin, triterpenoid, and steroid. ${ }^{17}$ Raghavendran et al. (2005) found that marine algal Sargassum polycystum from Rameswaram coast, India, contains triterpenoid and glycoside. ${ }^{18}$ Furthermore, phytochemical studies by Malaysian researcher, Daud et al. (2015) revealed that $S$. polycystum showed the positive results for metabolites of alkaloid, flavonoid, tannin, and steroid. ${ }^{19}$

\section{Total phenolic and total flavonoid contents}

Total phenolic content was determined from linear regression equation of the calibration curves of gallic acid (Figure 2a), by substituting Y value of the linear regression equation of gallic acid $\left(Y=0.0011 x+0.1833, R^{2}\right.$ $=0.9833$ ), with absorbance value of the extract to obtain $\mathrm{x}$ value which is equal with the total phenolic content of the extract sample in $\mu \mathrm{g} /$ $\mathrm{mL}$. Whereas, total flavonoid content was determined by substituting $\mathrm{Y}$ value of the linear regression equation of quercetin in Figure $2 \mathrm{~b}(\mathrm{Y}$ $\left.=0.0152 \mathrm{x}+0.0663, \mathrm{R}^{2}=0.9993\right)$ with absorbance value of the extract to obtain $\mathrm{x}$ value which is equal with the total flavonoid content of the extract sample in $\mu \mathrm{g} / \mathrm{mL}$. Total phenolic and total flavonoid contents of

Table 1: Phytochemical analysis of Eucheuma cottonii.

\begin{tabular}{lcccc}
\hline \multirow{2}{*}{ Metabolite } & \multicolumn{4}{l}{ Sargassum polycystum } \\
\cline { 2 - 5 } & $\mathrm{n}$-Hexane & Ethyl Acetate & Chloroform & Ethanol \\
\hline Saponin & - & - & - & - \\
Flavonoid & + & + & + & + \\
Triterpenoid & - & - & - & - \\
Steroid & + & + & + & + \\
Alkaloid & - & - & - & - \\
Tannin & + & - & + & - \\
Glycoside & + & + & + & + \\
\hline
\end{tabular}




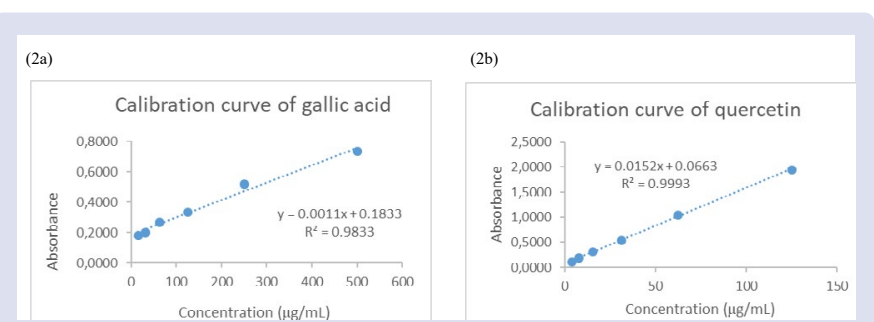

Figure 2: Calibration curve of gallic acid (a) and quercetin (b).

Sargassum polycystum extratcs were summarized in Table 2. As shown, ethylacetate extract has the highest phenolic content $(548.61 \mathrm{mg} / \mathrm{mL})$, followed by chloroform extract $(380.21 \mu \mathrm{g} / \mathrm{mL})$. The highest flavonoid content $(49.06 \mu \mathrm{g} / \mathrm{mL})$ containing in chloroform extract, followed by ethylacetate extract $(40.06 \mu \mathrm{g} / \mathrm{mL})$, whereas the $\mathrm{n}$-hexane and ethanolic extracts of Sargassum polycystum contained less amount of phenolic and flavonoid compounds.

\section{Thin layer chromatography (TLC) analysis of Sargassum polycystum extracts}

TLC analysis of Sargassum sp. using silica plate stationary phase, and a mixture of hexane and ethylacetate in a ratio of 1:1 as a mobile phase, UV lamp at $254 \mathrm{~nm}$ and $366 \mathrm{~nm}$ as a visualized spot (Figure 3). Retention factor (Rf) of $S$. polycystum extracts is displayed in Table 3. Hexane and ethylacetate extracts of $S$. polycystum have three spots, each at the $\mathrm{Rf}$ of $0.69,0.86$ and 0.97 in hexane extracts, and at the $\mathrm{Rf}$ of 0.17 , 0.86 and 0.97 in ethylacetate extract. Chloroform and ethanol extracts of $S$. polycystum have four spots respectively, at the Rf of $0.17,0.72,0.90$ and 0.97 in chloroform extract, and at the $\mathrm{Rf}$ of $0.14,0.72,0.83$ and 0.97 in ethanol extract. These results indicate that hexane and ethylacetate extracts contain three chemical components. Likewise, chloroform and ethanol extracts contain four chemical components. TLC results in Table 3 also showed that all these four extracts contain the same chemical compound at the $\mathrm{Rf}$ of 0.97 . Hexane and ethylacetate extracts of S. polycystum has the same spots at the Rf of 0.86 and 0.97 , indicating that both of extracts contain the same two chemical compounds. Moreover, ethylacetate and chloroform extracts of S. polycystum contain the same two chemical compounds at the Rf of 0.17 and 0.97 , while the chloroform and ethanol extracts of $S$. polycystum contain the same two chemical compounds at the Rf of 0.72 and 0.97 .

\section{Antioxidant Activity of Sargassum polycystum}

Antioxidant activity of ethylacetate and ethanol extracts of S. polycystum were evaluated as DPPH free radical scavenger, and depicted by $\mathrm{IC}_{50}$ value (Table 4). According to Marjoni et al. (2017), the $\mathrm{IC}_{50}$ value of antioxidant activity can be categorized into four levels: very strong, strong, moderate, and weak. $\mathrm{IC}_{50}$ value below $50 \mu \mathrm{g} / \mathrm{mL}$ is classified to have very strong antioxidant activity, $\mathrm{IC}_{50}$ value ranging from 50 to 100 $\mu \mathrm{g} / \mathrm{mL}$ is classified to have strong antioxidant activity, $\mathrm{IC}_{50}$ value ranging from 100 to $250 \mu \mathrm{g} / \mathrm{mLis}$ classified to have moderate antioxidant activity, $\mathrm{IC}_{50}$ value ranging from 250 to $500 \mu \mathrm{g} / \mathrm{mL}$ is classified to have weak antioxidant activity, and $\mathrm{IC}_{50}$ value over than $500 \mu \mathrm{g} / \mathrm{mL}$ is classified to have no antioxidant activity. ${ }^{20}$ As shown in Table 4, ascorbic acid (positive control) has the strongest antioxidant activity on DPPH free radical with $\mathrm{IC}_{50}$ of $6.47 \mu \mathrm{g} / \mathrm{mL}$. $\mathrm{IC}_{50}$ value of ethanol extract of S.polycystum with $\mathrm{IC}_{50}$ value of $624.76 \mu \mathrm{g} / \mathrm{mL}$, is assigned to have no antioxidant activity, whereas ethylacetate extract of $S$. polycystum with $\mathrm{IC}_{50}$ value of $298.32 \mu \mathrm{g} / \mathrm{mL}$ is assigned to have a weak antioxidant activity. Considering that ethylacetate extract of $S$. polycystum possess high total phenolic content $(548.61 \mu \mathrm{g} / \mathrm{mL})$ and high total flavonoid content $(40.06 \mu \mathrm{g} / \mathrm{mL})$, this result indicating that antioxidant activity of ethylacetate extracts of $S$. polycystum is directly correlated with its total phenolic and flavonoid contents.

\section{In Vitro cytotoxicity of Sargassum polycystum Against HeLa cells}

In vitro cytotoxicity of S. polycystum extracts and cisplatin as a positive control were determined by the MTT assay, and is expressed by the $\mathrm{IC}_{50}$ value. The smaller $\mathrm{IC}_{50}$ value, the stronger cytotoxicity. Table 5 summarizes cytotoxicity of cisplatin and four extracts of $S$. polycystum against HeLa cells. Atjanasuppat et al. (2009) classified anticancer activity of the extract into four groups based on $\mathrm{IC}_{50}$ value, as follows : $\mathrm{IC}_{50}$ value below $20 \mu \mathrm{g} / \mathrm{mL}$ is classified as an active anticancer agent, the $\mathrm{IC}_{50}$ value between $20-100 \mu \mathrm{g} / \mathrm{mL}$ is classified as a moderate active anticancer agent, $\mathrm{IC}_{50}$ value between $100-1000 \mu \mathrm{g} / \mathrm{mL}$ is classified as a weak anticancer agent, and $\mathrm{IC}_{50}$ value over $1000 \mu \mathrm{g} / \mathrm{mL}$ is classified as inactive agent. ${ }^{21}$ As shown in Table 5 , As cisplatin has a very strong cytotoxicity against HeLa cervical cancer cells with $\mathrm{IC}_{50}$ value of 14.5

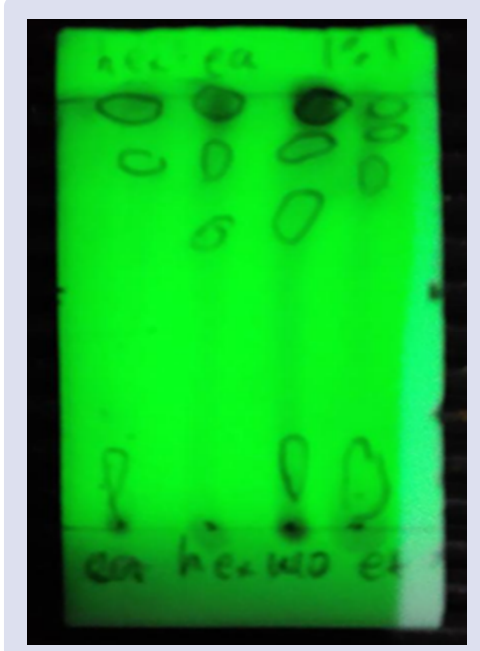

Figure 3: TLC analysis of Sargassum polycystum.

Ea: ethylacetate extract; hex: $n$-hexane extracts; klo: chloroform extract; Et: ethanol extract

Table 2: Total phenolic and total flavonoid contents of Sargassum polycystum extracts.

\begin{tabular}{ccc}
\hline $\begin{array}{c}\text { Extract of } \mathrm{S} . \\
\text { polycystum }\end{array}$ & Total Phenolic $(\mathrm{mg} / \mathrm{mL})$ & Total Flavonoid $(\mathrm{mg} / \mathrm{mL})$ \\
\hline n-Hexane & 233.91 & 28.56 \\
Ethyl acetate & 548.61 & 40.06 \\
Chloroform & 340.21 & 49.06 \\
Ethanol & 123.21 & 14.45 \\
\hline
\end{tabular}

Table 3: Retention factor (Rf) of Sargassum polycystum extracts.

\begin{tabular}{ccccc}
\hline Extract & \multicolumn{3}{c}{ Rf value } \\
\hline & 1 & 2 & 3 & 4 \\
\hline n-Hexane & 0.69 & 0.86 & 0.97 & - \\
Ethylacetate & 0.17 & 0.86 & 0.97 & - \\
Chloroform & 0.17 & 0.72 & 0.90 & 0.97 \\
Ethanol & 0.14 & 0.83 & 0.90 & 0.97 \\
\hline
\end{tabular}

${ }^{*} \mathrm{Rf}=$ Retention factor

Table 4: Antioxidant activity of Sargassum polycystum extracts against DPPH free radical.

\begin{tabular}{cc}
\hline Tested Sample & $\mathrm{IC}_{50}(\mu \mathrm{g} / \mathrm{mL})$ \\
\hline Ascorbic acid (positive control) & 6.47 \\
Ethylacetate extract of $S$. polycystum & 298.32 \\
Ethanol extract of $S$. polycystum & 624.76 \\
\hline
\end{tabular}


Table 5: Cytotoxicity of Sargassum polycystum extracts against HeLa cells.

\begin{tabular}{cc}
\hline Tested sample & $\mathrm{IC}_{50}(\mu \mathrm{g} / \mathrm{mL})$ \\
\hline Cisplatin (positive control) & 14.5 \\
n-hexane & 60.9 \\
Ethyl acetate & 112.0 \\
Chloroform & 38.3 \\
Ethanol & 112.8 \\
\hline
\end{tabular}

${ }^{*} \mathrm{IC} \mathrm{C}_{50}$ is the $50 \%$ half maximal inhibitory activity in $\mu \mathrm{g} / \mathrm{mL}$

$\mu \mathrm{g} / \mathrm{mL}$. N-hexane and chloroform extracts of Sargassum polycystum with $\mathrm{IC}_{50}$ values of $60.9 \mu \mathrm{g} / \mathrm{mL}$ and $38.3 \mu \mathrm{g} / \mathrm{mL}$, respectively, were classified to have a moderate cytotoxicity against HeLa cells. Whereas, ethylacetate and ethanol extracts of Sargassum polycystum were classified to have a weak cytotoxicity on HeLa cells with $\mathrm{IC}_{50}$ values of $112.0 \mu \mathrm{g} / \mathrm{mL}$ and $112.8 \mu \mathrm{g} / \mathrm{mL}$, respectively. Compared to other extracts, chloroform extract which has the smallest $\mathrm{IC}_{50}$ value $(38.3 \mu \mathrm{g} /$ $\mathrm{mL})$ and the highest total flavonoid content $(49.06 \mu \mathrm{g} / \mathrm{mL})$ exhibited the strongest cytotoxicity against HeLa cervical cancer cells. This result suggesting that chloroform extracts that contains high concentration of flavonoid, as well as containing metabolites of steroid, glycoside, and tannin is more effective as anticancer agent against cervical HeLa cells. Flavonoids are well known showing effectivity and interaction with several pathways to inhibit diseases, particularly as an antioxidant and anticancer agents. Flavonoids involve in the mechanism to treat cancers, such as to induce apoptosis, as carcinogenic enzyme and metabolism inhibitors, as well as to induce differentiation. ${ }^{22,23}$ Steroid is also known to have ability in inhibiting the progression of cancer, whereas tannin showed antibiotic activity to prevent oral infection caused by dental biofilm. ${ }^{24}$ Another study by Sakagami et al. (2000) revealed that tannins possessed cytotoxic effect on squamous cells carcinoma by inducing apoptosis. ${ }^{25}$ Thus, the cytotoxicity of chloroform extract of S. polycyctum this study might be due to the presence of flavonoid, steroid, glycoside, and tannin.

\section{CONCLUSION}

Chloroform extract of Sargassum polycystum demonstrated the strongest cytotoxicity against cervical HeLa cells ( IC $_{50}$ value of $38.3 \mu \mathrm{g} /$ $\mathrm{mL}$ ), which is potential to be developed as a candidate for new anticervical cancer agents. Whereas ethylacetate extract of Sargassum polycytum with $\mathrm{IC}_{50}$ value of $298.32 \mu \mathrm{g} / \mathrm{mL}$ on DPPH free radical, is potential to be developed as a natural antioxidant.

\section{ACKNOWLEDGEMENT}

We thank to Ministry of Research and Technology and Higher Education (Kemenristek-DIKTI), Republic of Indonesia, and Directorate of Research and Public Service (DRPM), University of Indonesia, for the PDUPT (Penelitian Dasar Unggulan Perguruan Tingi) research grant for fiscal year 2019 (contract number: 1525/UN2. R3.1/HKP05.00/2019).

\section{CONFLICTS OF INTEREST}

The authors declare no conflicts of interest.

\section{ABBREVIATIONS}

TLC: Thin layer chromatography; DPPH: (2,2-diphenyl-1picrylhydrazyl) MTT: (3-(4,5-Dimethylthiazol-2-yl)-2,5Diphenyltetrazolium Bromide); IC $_{50}$ : median Inhibitory Concentration; $\boldsymbol{\mu g} / \mathbf{m L}$ : microgram/milliliter; HeLa: Henrietta Lacks; g: gram; $\mathbf{m L}$ : millimeter; N: Normality; UV-Vis: Ultra violet-Visible, RPMI: Rosewell Park Memorial Institute; $\mathbf{h}$ : hour; PBS: Phosphate-Buffered Saline; ${ }^{\circ} \mathbf{C}$ : degree Celsius; $\boldsymbol{\mu L}$ : microliter; $\mathbf{C O}_{2}$ : Carbon dioxide; Rf: Retention factor; USA: United States of America.

\section{REFERENCES}

1. Bruni L, Barrionuevo-Rosas L, Albero G, Serrano B, Mena M, Gomez D et al. Information Centre on HPV and Cancer. Human Papillomavirus and Related Disease in Indonesia. Summary Report, 19 April 2017 [Date accessed].

2. Lage H. Cancer Therapy. 2003;1:81.

3. Aziz MF, Andrijono A, Saifuddin AB. Onkologi dan Ginekologi: Buku Acuan Nasional. Yayasan Bina Pustaka Sarwono Prawirohardjo, Jakarta, Indonesia. 2006:442-55.

4. Kim EJ, Park SY, Lee J-Y, Park JHY. Fucoidan present in brown alga induces apoptosis of human colon cancer cells. BMC Gastroentology. 2010;10:96.

5. Lee J-C, Hou M-F, Huang H-W, Chang F-R, Yeh C-C, Tang J-Y, Chang H-W Marine algal natural product with anti-oxidative, anti-inflamatory, and anticancer properties. Cancer Cell International. 2013;13:55.

6. Michanek G. Seaweed resources for pharmaceutical uses. In Marine Algae in Pharmaceutical Science, Walter de Gruyter, Berlin, New York. 1979:203-27.

7. Noda H, Amano H, Arashima K, Nizizawa K. Antitumor Activity of Marine Algae. Hydrobiologia. 1990;204:577-84.

8. Arsianti A, Fadilah F, Bahtiar A, Dewi MK, Adyasa ZM, Simadibrata DM, Amartya D. Phytochemistry profile and in vitro cytotoxicity of seaweed macroalgae Sargassum polycystum against colon HCT-116 and lung A-549 cancer cells. International Journal of Green Pharmacy. 2019;13(2):141-6.

9. Luning K. Seaweed Their Environment, Biogeography and Ecophysiology. John Wiley and Sons, New York. 1990.

10. Atmadja WS, Kadi A, Sulistidjo, Rachmaniar. Pengenalan Jenis-Jenis Rumput Laut. Pusat Penelitian dan Pengembangan Oseanologi LIPI. Jakarta, Indonesia. 1996:191.

11. Kadi A. Beberapa Catatan Kehadiran Marga Sargassum di Perairan Indonesia. Oseana. 2005;4:19-29

12. Harborne JB. Metode Fitokimia. Penuntun Cara Modern Menganalisis Tumbuhan. 1987. Penerbit ITB Bandung. http://library.sith.itb.ac.id/ index.php? menu=library\&action=detail \&library ID=5577.

13. Ciulei I. Methodology for analysis of vegetable drugs, practical manuals on industrial utilization of medicinal and aromatic plant. Phytochemistry. 1982;63(1):97.

14. Banerjee D, Chakrabarti S, Hazra AK, Banerjee S, Ray J, Mukherjee B Antioxidant activity and total phenolics of some mangroves in Sundarbans. African Journal of Biotechnology. 2008;7(6):805-10.

15. Do QD, Angkawijaya AE, Tran-Nguyen PL, Huynh LH, Soetaredjo FE, Ismadji S, JuY. Effect of extraction solvent on total phenol content, total flavonoid content and antioxidant activity of Limnophila aromatica. Journal of Food and Drug Analysis. 2013;22:296-302

16. Rajurkar NS, Hande SM. Estimation of phytochemical content and antioxidant activity of some selected traditional indian medicinal plants. Indian Journal of Pharmaceutical Sciences. 2011;2:146-51.

17. Mehdinezhad N, Ghannadi A, Yegdaneh A. Phytochemical and biological evaluation of some Sargassum species from Persian Gulf. Res Pham Sci. 2016;11(3):243-9

18. Raghavendran BH, Sathivel A, Devaki T. Antioxidant effect of Sargassum polycystum (Phaeophyceae) against acetaminophen induced changes in hepatic mitochondrial enzymes during toxic hepatitis. Chemosphere. 2005;61:278-81

19. Daud N, Noor NN, Alimon H, Rashid NA. Preliminary toxicity test and phytochemical screening of Sargassum polycystum crude extracts from marine macroalgae. ESTEEM Academic Journal. 2015;11(1):109-16.

20. Marjoni MR, Zulfisa A. Antioxidant activity of methanol extract/fractions of senggani leaves (Melastoma candidum D. Don). Pharm Anal Acta. 2017;8(8):16.

21. Atjanasuppat K. Wongkham W, Meepowpan P, Kittakoop P, Sobhon P, Bartlett A, Whitfield PJ. In vitro screening for anthelmintic and antitumour activity of ethnomedicinal plants from Thailand. J Ethnopharmacol. 2009;123:475-82.

22. Wang T, Li Q, Bi K. Bioactive flavonoids in medicinal plants: Structure, activity and biological fate. Asian Journal of Pharmaceutical Sciences. 2018;13:12-23.

23. Iqbal J, Abbasi BA, Mahmood T, Kanwal S, Ali B, Shah SA, Khalil AT. Plantderived anticancer agents: A green anticancer approach. Asian Pac J Trop Biomed. 2017:7(12):1129-50.

24. Pai BHM, Rajesh G, Shenoy R, Rao A. Anti-microbial efficacy of soursop leaf extract (Annona muricata) on oral pathogens: An in-vitro study. J Clin Diagnostic Res. 2016;10(11):ZC01-4.

25. Sakagami H, Jiang Y, Kusama K, Atsumi T, Ueha T, Toguchi M, Iwakural, et al Cytotoxic activity of hydrolysable tannins against human oral tumor cell lines - A possible mechanism. Phytomedicine. 2000;7:39-47. 


\section{GRAPHICAL ABSTRACT}

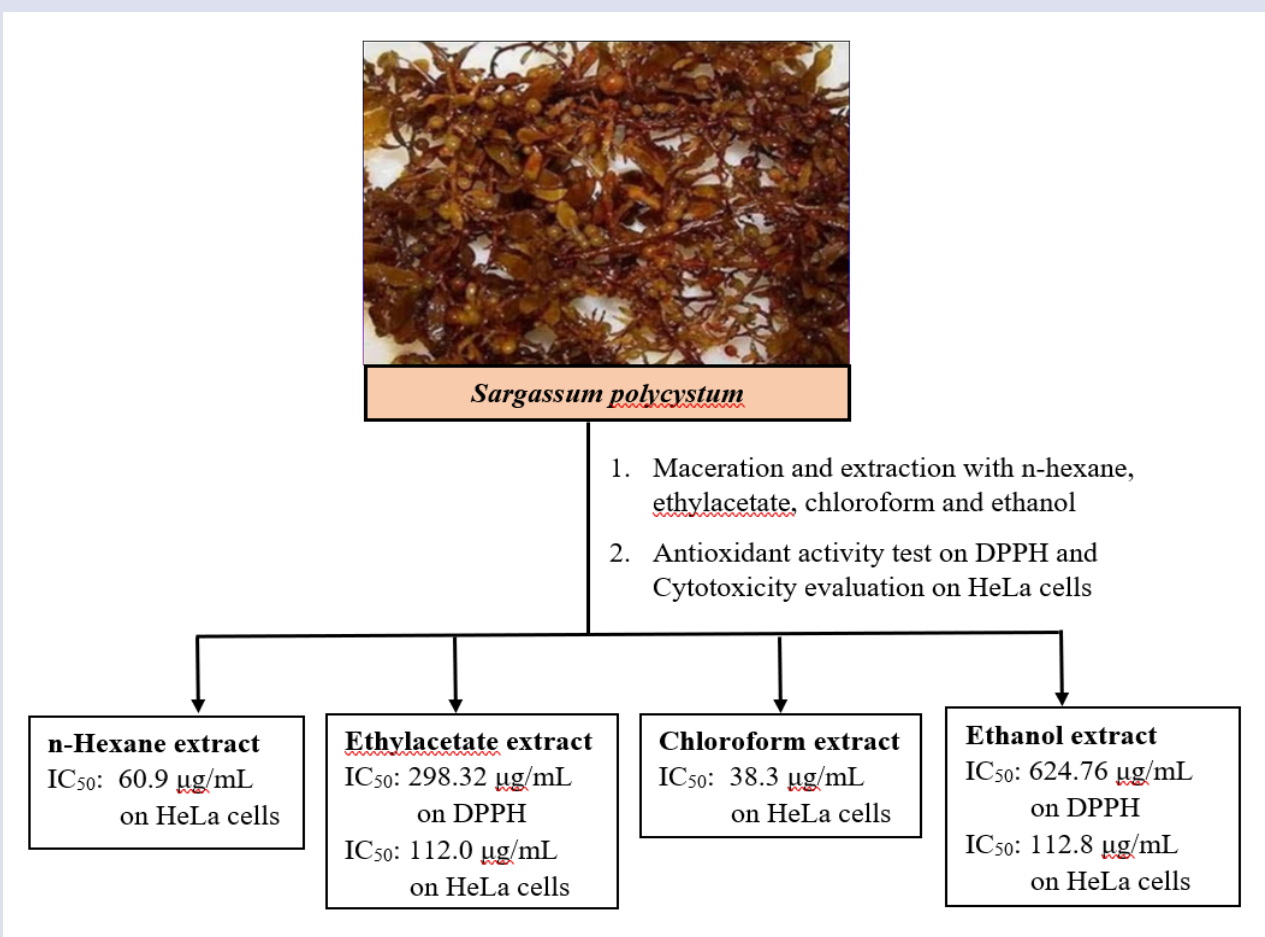

\section{SUMMARY}

Marine algal Sargassum polycystum collected from Dompu beach, Nusa Tenggara Barat, Indonesia showed potent antioxidant anti-cervical cancer activities. Phytochemical analysis of S. polycystum extracts are positive for metabolites of flavonoid, steroid, tannin and glycoside. TLC analysis revealed that S. polycystum extracts containing four phytochemical components. Ethylacetate extract of S. polycystum with $I_{50}$ value of $298.3 \mu \mathrm{g} / \mathrm{mL}$ exhibited a weak antioxidant activity against DPPH free radical. Moreover, S. polycystum extracts demonstrated a strong cytotoxicity against cervical HeLa cells with $\mathrm{IC}_{50}$ ranging from $38.3 \mu \mathrm{g} / \mathrm{mL}$ to 112.8 $\mu \mathrm{g} / \mathrm{mL}$.

\section{ABOUT AUTHORS}

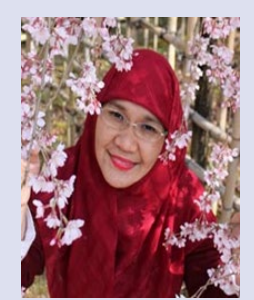

Dr. Ade Arsianti: Lecturer and Researcher at Medical Chemistry Department and Drug Development Research Center (DDRC), Indonesian Medical Education and Research Institute (IMERI), Faculty of Medicine, Universitas Indonesia. Research interest in medicinal chemistry, synthetic organic chemistry, natural product chemistry, and marine natural product.

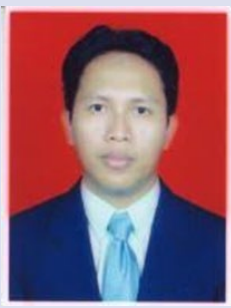

Dr. Anton Bahtiar: Lecturer and Researcher at Department of Pharmacology, Faculty of Pharmacy, Universitas Indonesia. Research interest in molecular pharmacology and herbal medicine.

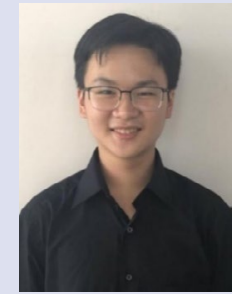

Vincent Kharisma Wangsaputra: Third-year medical student in Faculty of Medicine, Universitas Indonesia. Despite technological advancement in treatment and sophisticated therapeutic strategies, neoplasm still remains as the focus of medical problem causing mortality and morbidity. Many researches have been conducted in order to figure out substances that have high potential of anticancer or cytotoxic activity, especially in combating cell resistance. My personal interest of research includes the utilization and incorporation of Indonesian natural compound to be scientifically applied in a way that it can yield eficient antitumorigenic properties towards the cancer cells. 

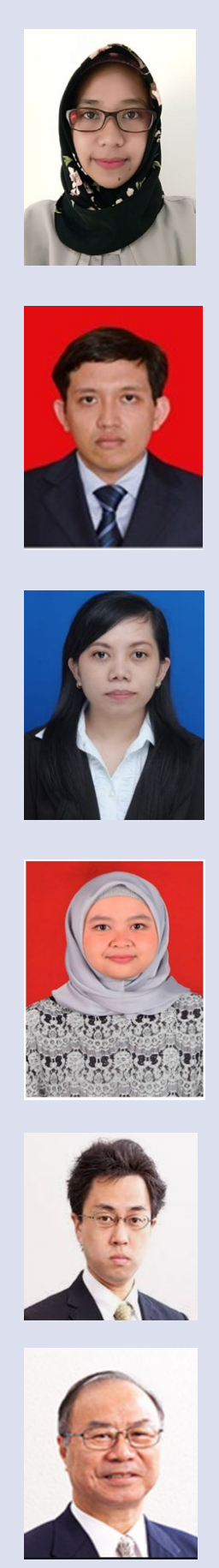

Norma Nur Azizah: Researcher at Drug Development Research Center (DDRC), Indonesian Medical Education and Research Institute (IMERI), Faculty of Medicine, Universitas Indonesia. Research interest in tissue culture, analytical chemistry, and natural product chemistry.

Wilzar Fachri: Lecturer at Department of Medical Pharmacy Faculty of Medicine, University of Indonesia and Researcher at Drug Development Research Center Cluster, Indonesian Medical Education and Research Institute, Faculty of Medicine, University of Indonesia. Research interest are in Drug Discovery and Development from Herbal Medicine, Cell and Tissue Culture, Animal Models, Cancer and Metabolic Syndrome Researches.

Lince Dameria Nadapdap: Researcher at Drug Development Research Center (DDRC), Indonesian Medical Education and Research Institute (IMERI), Faculty of Medicine, Universitas Indonesia. Research interest in synthetic organic chemistry, analytical chemistry, and natural product chemistry.

Ajeng Megawati Fajrin: Researcher at Department of Medical Chemistry, Faculty of Medicine, Universitas Indonesia. Research interest in tissue culture, analytical chemistry, and natural product chemistry.

Dr. Hiroki Tanimoto: Assistant Professor and researcher in Synthetic Organic Chemistry Laboratory, Graduate School of Materials Science, Nara Institute of Science and Technology (NAIST), Japan. Research interest in organic synthesis.

Professor Kiyomi Kakiuchi: Researcher in Synthetic Organic Chemistry Laboratory, Graduate School of Materials Science, Nara Institute of Science and Technology (NAIST), Japan. Research interest in organic synthesis.

Cite this article: Arsianti A, Bahtiar A, Wangsaputra VK, Azizah NN, Fachri W, Nadapdap LD, et al. Phytochemical Composition and Evaluation of Marine Algal Sargassum polycystum for Antioxidant Activity and In Vitro Cytotoxicity on Hela Cells. Pharmacog J. 2020;12(1):88-94. 